\title{
Preoperative, intraoperative approachs in ovarian mature cystic teratomas: analysis of 96 cases
}

\section{Over matür kistik teratomlarında preoperatif, intraoperatif yaklaşımlar: 96 olgunun analizi}

\author{
Funda Atalay
}

SBÜ Dr. AY Ankara Onkoloji Eğitim Ve Araştırma Hastanesi Jinekolojik Onkoloji Cerrahisi Kliniği, Ankara, Türkiye

Dergiye Ulaşma Tarihi: 04.06.2018 Dergiye Kabul Tarihi:13.06.2018 Doi: 10.5505/aot.2018.30592

\section{ÖZET}

GiRiş ve AMAÇ: Matür kistik teratom olgularının tümör karakteristikleri, tümör belirteçleri, preoperatif, intraoperatif özellikleri ve cerrahi tedavileri açısından retrospektif olarak değerlendirilmesi YÖNTEM ve GEREÇLER: SBÜ Dr.AY. Ankara Onkoloji Eğitim ve Araştırma Hastanesi Kadın hastalıkları kliniğinde opere edilen ve histopatolojik olarak ovaryan matür kistik teratom tanısı alan toplam 96 olgu retrospektif olarak analiz edildi.

BULGULAR: Olguların yaş ortalaması $33,84 \pm 13,16$, bilateralite oranı $\% 9,4$, torsiyon görülme oran $1 \% 10,4$ idi,

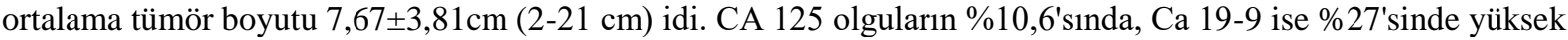
bulundu. Tümör belirteçlerinin yüksek olduğu olgularda torsiyon, bilateralite ve tümör boyutlarında anlamlı yükseklik gözlenmedi.

TARTIŞMA ve SONUÇ: Tümör belirteçlerinin tümör özelliklerinden bilateralite, torsiyon ve tümör boyutu üzerine etkisi gözlenmedi.

Anahtar Kelimeler: over, matür kistik teratom, ultrasonografi, tümör belirteçler

ABSTRACT
INTRODUCTION: The aim of the study is to evaluate tumor characteristics, tumor markers, preoperative, intraoperative approach in ovarian mature cystic teratomas. retrospectively. METHODS: A total 96 cases operated in Gynecology Deparment of SBU Dr.AY Ankara Oncology Education and Research Hospital and diagnosed as ovarian mature cystic teratomas were evaluated, retrospectively. RESULTS: The mean age was 33,84 $\pm 13,16$, bilaterality range was $\% 9,4$, torsion rate was $\% 10,4$ and the mean tumor diameter was $7,67 \pm 3,81 \mathrm{~cm}(2-21 \mathrm{~cm})$. Ca125 levels were high above the cut-off value $10,6 \%$ of cases and Ca 19-9 levels were high above the cut-off value in $27 \%$. There were no high rates of torsion, bilateralty and tumor size in cases with high levels of tumor markers.

DISCUSSION AND CONCLUSION: There were no correlation between high levels of tumor markers and torsion, bilaterality and tumor size.

Keywords: ovary, mature cystic teratoma, ultrasonography, tumor markers

\section{GÍRIS}

Matür kistik teratomlar (MKT) overin en sik görülen germ hücreli tümörleridir, embriyonal olarak overin üç germ tabakasının farklılaşmasıyla oluşmakta ve bu üç germ tabakasından da dokular (sebase, k1l, diş, kemik vb.) içermektedir. Tüm over tümörleri arasında görülme sıklığı $\% 10-20$ arasında değişmektedir. Üreme çağındaki kadınlarda ise (20-40 yaş) en s1k görülen over tümörüdür (\%45-70) (1,2). MKT'lar rutin pelvik muayene sırasında tanı alabileceği gibi ağrı, torsiyon, rüptür gibi akut batın bulgularıyla da karşılaşılabilir (3). Malign transformasyon nadir görülen fakat ciddi bir komplikasyondur, 45 yaş üzeri ve $10 \mathrm{~cm}$ 'den büyük tümörlerde akılda tutulmalıdır (4.5). Tanı klinik bulgular, 
ultrasonografi (USG) ve/veya diğer görüntüleme yöntemlerine (magnetik rezonans MR, bilgisayarlı tomografi BT) dayanır. Tipik ultrasonografik görüntüleriyle diğer over tümörlerinden ayırt edilmeye çalışılır $(6,7,8$,$) .$ Ayrıca son yıllarda tümör belirteçlerinden özellikle Ca 19-9'un MKT tanısının konmasında, preoperatif dönemde özellikle yapılacak cerrahinin planlanmasındaki rolü ile ilgili çalışmalar yapılmaktadır $(9,10)$. Üreme çağındaki kadınlarda yüksek oranda görüldüğü için cerrahi tedavide fertilitenin korunmas1 önem arz etmektedir burdan yola çıkarak MKT'ların tedavisinde laparoskopik cerrahi açık cerrahiye tercih edilir olmuştur (11). Bu çalışmada MKT olgularının tümör karakteristikleri, tümör belirteçleri, preoperatif, intraoperatif özellikleri ve cerrahi tedavileri açısından retrospektif olarak değerlendirilmesi ve bu konudaki günlük pratiğin, deneyimin literatür bilgileri eşliğinde tartışılması amaçland1.

\section{GEREÇ ve YÖNTEMLER}

2010-2017 yılları arasında Ankara Onkoloji Eğitim ve Araştırma Hastanesi Kadın hastalıkları kliniğinde tedavi edilen 96 ovaryan matür kistik teratom olgusunun verileri retrospektif olarak analiz edildi. Olguların yaş, preoperatif görüntüleme (USG, MR, BT), görüntüleme bulguları (boyut, bilateralite, torsiyon), tümör belirteçleri (Ca125, Ca19,9), yapılan cerrahi işlem (kistektomi, salpingoooferektomi, histerektomi) ve patoloji sonuçları arşiv kayıtlarından alınarak kaydedildi. Yapılan çalışmada görüntülemede MKT tanısı, raporlarda MKT/ dermoid kist tanı olarak rapor edilmesi durumunda kabul edildi. Tümör boyutu olarak en büyük çap cm olarak alındı. CA $125<35 \mathrm{U} / \mathrm{ml}, \mathrm{Ca}$ 19-9<39 U/ml değerleri normal olarak kabul edildi. Elde edilen bulguların (kist boyutu, bilateralite varlı̆ğ, torsiyon varlığ1, Ca 125 ve Ca19-9 düzeyleri,
Ca 125 ve Ca19-9 düzeylerine göre bilateralite ve torsiyon varlığı ve tümör boyutu) istatistiksel değerlendirilmesinde SPSS 15 programı kullanıldı.

\section{BULGULAR}

Olguların yaş ortalaması $33,84 \pm 13,16$, bilateralite oran $\% 9,4$, torsiyon görülme oranı $\% 10,4$ idi, ortalama tümör boyutu $7,67 \pm 3,81 \mathrm{~cm} \quad(2-21 \quad \mathrm{~cm}) \quad$ idi. Tümör belirteçlerinden $\mathrm{Ca}$ 125, 85 olguda, Ca 19-9 ise 74 olguda bakılmış olup, CA 125 olguların $\% 10,6$ 'sında, Ca 19-9 ise \%27'sinde yüksek bulundu (Tablo1). 51 olgu kistektomi,29 olgu unilateral salpingoooferektomi, 16 olgu ise total abdominal histerektomi ve bilateral salpingoooferektomi ile tedavi edildi (Tablo2). Ca 125 'in $35 \mathrm{U} / \mathrm{ml}$ 'nin üzerinde bulunduğu 9 hastadan 1 tanesinde torsiyon, 1 tanesinde bilateral tümör tespit edildi. Ca 125 yüksekliği tümör boyutu açısından değerlendirildiğinde $10 \mathrm{~cm}$ kriter olarak alındığında 9 hastanın 2'sinde tümör boyutunun $10 \mathrm{~cm}$ üzerinde olduğu görüldü. Bu kriterler Ca 19-9 yüksek olan 20 hasta açısından değerlendirildiğinde torsiyon 2, bilateralite 3 hastada pozitif bulunurken 4 hastada tümör boyutu $10 \mathrm{~cm}$ üzerindeydi(Tablo3). Çalışmada 86 hastanın görüntüleme raporlarına ulaşıldı. $\mathrm{Bu}$ hastalardan 44'ü $(\% 51,2)$ yalnız USG, 42'si $(48,8)$ ise USG 'ye ek olarak MR veya BT ile değerlendirilmişti. Görüntüleme raporlarına ulaşılan hastalardan \%65,11'ine (56/86) görüntüleme ile MKT tanısı konulmuş olup yalnız USG yapılan hastalarda bu oran $\% 40,9$ (18/44) iken USG + MR veya BT ile değerlendirilen hastalarda \%90,47 (38/42) oranında MKT tanısının raporlandığı tespit edildi.

\section{TARTIŞMA}

Bu çalışmada matür kistik teratom olgularının tümör karakteristikleri, tümör belirteçleri, preoperatif, intraoperatif özellikleri ve cerrahi tedavileri retrospektif olarak değerlendirilmiş 
ve konudaki günlük pratik, deneyim literatür bilgileri eşliğinde tartışılmıştır.

Matür kistik teratomlar üreme çağında en sık karşılaşılan benign tümörlerdir $(1,2)$. Bu çalışmada ortalama görülme yaşı $33,84 \pm 13,16$ ile literatürle uyumluydu. MKTlerin preoperatif değerlendirilmesinde görüntüleme, özellikle ultrasonografi tanıda yardımcıdır. Ultrasonografide MKT için tanımlanmış tipik radyolojik bulgular mevcuttur $(6,12)$. Yine MR ve BT yağ dokusu açısından daha spesifik olduğundan ve MKTlerdeki yoğun sebasöz içerikten dolayı tanı şansını yükseltmektedir $(7,8)$. Kahraman ve ark. çalışmalarında vakaların 2/3'ünde ultrasonografi ve histopatolojik tanının uyumlu olduğunu göstermişler (13). Mevcut çalışmada yalnı USG ile \%40, USG + MR/ BT ile ise \%90,47 oranında MKT tanısı doğrulanmıştır. Preoperatif adneksiyal kitlesi olan hastaların değerlendirilmesinde en önemli husus malignite varllğının tespiti ve buna göre yapılacak cerrahi girişimin planlanmasıdır. Malignitenin preoperatif değerlendirilmesinde tümör belirteçleri önemli rol almaktadır. Yapılan çalışmalar MKT olgularında tümör belirteçlerinin tanısal değerinin düşük olduğunu göstermektedir $(13,14)$. Ca 125 over tümörlerinin tanısında en sık kullanılan tümör belirtecidir. MKTlarda Ca125 değerleri \%12,7\%24 oranında yüksek bulunmuştur $(9,10$, 15,16). Dede ve ark çalışmalarında Ca 125 düzeyleri $\% 25$ olguda, Güzin ve ark.ise \%16,7 olguda yüksek bulunmuştur $(17,18)$. Ca 19-9 MKT'larda en çok çalışlan diğer bir tümör belirtecidir. Ca19-9'un MKTlarda respiratuar glandlar ve mukozadan üretildiği öngörülmüş ve \%50'ye varan oranlarda MKT olgularında yüksek bulunduğu literatürde belirtilmiştir (10, 15,17,19). Mevcut çalışmada CA 125 değerleri olguların \%10,6'sında, Ca 19-9 ise \%27'sinde yüksek bulundu. Ca125 ve Ca19-9 değerlerinin MKTlarda yüksek bulunması dışında, bu belirteçlerin yüksekliği ile tümör boyutu, bilateralite ve torsiyon gibi bazı tümör özellikleri arasında korelasyon bulunduğuna yönelik sonuçları birbiriyle çelişen bazı çalışmalar mevcuttur( $10,13,14)$. Dede ve arkadaşlarının çalışmasında, yüksek Ca19-9 ve Ca125 değerleri ile bilateralite arasında ilişki olduğu bildirilmiş ancak Üstünyurt ve ark. çalışmalarında Ca19-9 düzeyi yüksekliği ile bilateralite arasında ilişki bulamamışlardı $(14,17)$ Üstünyurt ve ark.ile Güzin ve ark. çalışmalarında yüksek Ca19-9 düzeyi ile sadece tümör ortalama çap1 arasında korelasyon tespit edilmiş, bilateralite ile ilişki saptanmamıştır $(14,18)$. Bu konudaki diğer bir çalışmada Yeşilyurt ve ark 26-35 yaş arasındaki hastalarda Ca19-9 yüksekliği ile tümör boyutu arasinda bir korelasyon olduğunu göstermişlerdir (10). Bu çalışmada ise tümör belirteçlerinin yüksek olduğu olgularda torsiyon, bilateralite ve tümör boyutlarında anlamlı yükseklik gözlenmedi.

Matür kistik teratomların tedavisinde yaş ve fertilite arzusu uygulanacak cerrahinin belirlenmesinde en önemli faktörlerdir (1-,3). MKTlar en sık üreme çağında, çoğunlukla 2030'lu yaşlarda karşımıza çıktığından tedavi olabildiğince konservatif ve fertiliteyi koruyucu yönde olmalıdır. Geçmiş yıllarda MKTların tedavisinde laparatomi ile ooferektomi veya USO standart yaklaşım iken, günümüzde laparaskopik kistektomi siklıkla tercih edilen yöntemdir (11). Cerrahinin hangi yolla yapılacağı operatörün tecrübesi, tümör boyutu, hastanın menopozal durumu, ek cerrahi gerektirebilecek patolojilerin varlığ gibi faktörlere bağlıdır. Kliniğimizde standart cerrahi yöntem olarak laparatomi tercih edilmektedir, bu nedenle tüm olgularda açık cerrahi uygulanmış ancak hastaların yaşı, fertilite arzusu, menopoz durumu ve ek patolojileri dikkate alınarak fertilitenin korunmasına dikkat edilmiş, olguların \%83,3'ünde fertilite korunmuş, 51 olgu kistektomi ile tedavi edilmiştir.

Matür kistik teratomlarda görülen komplikasyonlar torsiyon, rüptür, enfeksiyon ve malign transformasyon olarak tanımlanmıştır. Torsiyon \%3-16 ile en sık 
görülen komplikasyondur $(1,3,11,20)$. $\mathrm{Bu}$ çalışmada torsiyon gürülme sıklığ $\% 10,4$ ile literatürle uyum göstermektedir. Çalışmamızda rüptür ve enfeksiyon rapor edilmemiştir. Nadir görülmekle birlikte en önemli komplikasyon malign transformasyondur. En sık görülen tipi yass1 hücreli karsinomdur. Malign transformasyon ile tümör belirteçleri arasında bir korelasyon gösterilememiş olmakla birlikte \%70'den fazla olguda Ca125 veya Ca19-9 düzeylerinin yüksek olduğu bildirilmiştir $(4,5,13)$. Bizim çalışmamızda tümör belirteçlerinin yüksek olduğu olgular da dahil olmak üzere takip süresince malign transformasyon görülmedi.

Sonuç olarak MKTlar üreme çağında en sık görülen benign over tümörlerdir. Preoperatif USG+MR/BT ile olguların büyük bir çoğunluğunda tanı öngörülebilmektedir. Preoperatif bakılan tümör belirteçlerinin tanısal değeri düşüktür, bununla birlikte Ca19-9 değerleri olguların yarısından çoğunda yüksek bulunmaktadır. Preoperatif tanısal değeri olmamakla birlikte malign over tümörlerinden ayırt etmek ve yapılacak cerrahi girişimi planlamak için tümör belirteçleri bakılmalıdır. Üreme çağında görülme sıklığı yüksek olduğundan minimal invaziv cerrahi girişimle tedavi edilmeli, tedavi planlanırken hastanın yaşı, fertilite arzusu ve eşlik eden ek patolojiler göz önünde bulundurulmalıdır.

Çıkar Çatışması: Yok

Table 1. Olguların klinik özellikleri

\begin{tabular}{|c|c|}
\hline & $(\mathrm{n}=96)$ \\
\hline Yaş $(y ı l)^{a}$ & $33,84 \pm 13,16(15-77)$ \\
\hline Tümör boyutu $(\mathbf{c m})^{\mathrm{a}}$ & $7,67 \pm 3,81$ \\
\hline Bilateralite $^{b}$ & $9((9,4)$ \\
\hline Torsiyon $^{b}$ & $10(10,4)$ \\
\hline Ca125 bakılan hasta & $85(88,5)$ \\
\hline Ca19-9 bakılan hasta & $74(77,1)$ \\
\hline Yüksek Ca125 $^{b}$ & $9(10,6)$ \\
\hline Yüksek Ca19-9 $^{b}$ & $20(27)$ \\
\hline Görüntüleme yapılan hastab & $86(89 ; 6)$ \\
\hline $\mathbf{U S G}^{\mathbf{b}}$ & $44(51,2)$ \\
\hline $\mathrm{USG}+\mathrm{MR} / \mathbf{B T}^{\mathrm{b}}$ & $42(48,8)$ \\
\hline
\end{tabular}

${ }^{\mathrm{a}}$ Ortalama \pm standart sapma (min-max)

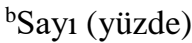


Table 2. Olguların operatif özellikleri

\begin{tabular}{|c|c|}
\hline Cerrahi tipi & \\
Kistektomi & $51(53,1)$ \\
USO $^{\mathbf{a}}$ & $29(30,2)$ \\
TAH+BSO $^{\mathbf{b}}$ & $16(16,7)$ \\
\hline İntraoperatif frozen & $\mathbf{5 3 ( 5 5 , 2 )}$ \\
\hline
\end{tabular}

${ }^{\mathrm{a}}$ unilateral salpingoooferektomi

${ }^{b}$ total abdominal histerektomi bilateral salpingoooferektomi

Tablo 3. Yüksek Ca125 ve Ca19-9 düzeyleri ile tümör özelliklerinin değerlendirilmesi

\begin{tabular}{|c|c|c|}
\hline & Yüksek Ca125(>35U/ml)(n=9) & Yüksek Ca19-9 $(>39 \mathrm{U} / \mathrm{ml})(\mathrm{n}=20)$ \\
\hline \multicolumn{3}{|l|}{ Tümör boyutu(cm) } \\
\hline$<10$ & $7(77,8)$ & $4(20)$ \\
\hline$>10$ & $2(22,2)$ & $16(80)$ \\
\hline \multicolumn{3}{|l|}{ Lateralite } \\
\hline Unilateral & $8(88,9)$ & $17(85)$ \\
\hline Bilateral & $18(11,1)$ & $3(15)$ \\
\hline \multicolumn{3}{|l|}{ Torsiyon } \\
\hline Var & $1(11,1)$ & $2(10)$ \\
\hline Yok & $8(88,9)$ & $18(90)$ \\
\hline
\end{tabular}

Değerler sayı ile birlikte yüzde olarak verilmiştir

\section{REFERENCES}

1. Pathore $\mathrm{R}$, sharma $\mathrm{S}$, Arora $\mathrm{d}$. Clinicopathological evaluation of 223 Cases of Mature Cysyic Teratoma, Ovary:25-Year Experience in a Single Tertiary Care Centre in India. J Clin and Diag Res. 2017;11(49:1-14.
2. Ayhan A, Bukulmez O, Genc C, Karamursel BS, Ayhan A. Mature cystic teratomas of the ovary:case series fron one institution over 34 years. Eur J Obstet Gynecol. 2000; 8882): 15357 
3. Commerci JT, Licciardi F, Bergh PA et al. Mature cystic teratoma: a clinicapathologic evaluation of 517 cases and review of the literature. Obstet Gynecol. 1994; 84(1)22-28

4. Hackethal A, Bregmann D, Bohlman MK, Franke FE, Tinneberg HR, Münstedt K. Squamous cell carcinoma in mature cystic teratoma of the ovary: systematic review and analysis of published data. Lancet Oncol. 2008; 9: 1173-80(18).

5. Oranratanaphan S, Khemapech N. Characteristics and treatment outcomes of patients with malign transformation arising from mature cystic teratoma of the ovary: experience at a single institution. Asian Pas J Cancer Prev. 2013;14(8): 4693-97.

6. Patel Md, Feldstein VA, Lipson SD, Chen DC, Filly RA. Cysyic teratoma of the ovary: diagnostic value of sonography. AJR Am J Roentgenol. 1998; 171: 1061-65(8

7. Buy JN, Ghossain MA, Moss AA, et al. Cysyic teratoma of the ovary: CT detection. Radiology. 1989; 171: 697-01)11

8. Guinet C, Buy JN, Ghossain MA. Fat suppression techniques in MR imaging of mature ovarian teratomas: comparson with $\mathrm{CT}$. Eur J Radiol. 1993; 17: 117-21(12

9. Coşkun A, Kiran G, Özdemir O. Ca19-9 can be a useful tumor marker in ovarian dermoid cysts. Clin Exp Obstet Gynecol. 2008; 35: 137-9

10. Yeşilyurt H, Seçkin B, Aktulay A, Ozyer S. Age-stratified analysis of tumor markers and tumor characteristics in adolescents and young women with mature cystic teratomas. J Chinese Med Ass. 2017; 1-6.

11. Özer A, Kıran H. Analysis of the factors determining the type of surgical procedure in mature cystic teratomas. Ginokologica Polska. 2017; 88(3): 134-37

12. Hertzberg BS, Kliewer MA. Sonography of benign cystic teratoma of the ovary: pitfalls in diagnosis. AJR Am J Roentgenol. 1996;167;1217-33
13. Kahraman K, Tülek F, Taşkın S, Tolunay E, Dökmeci F. Overyan matür kistik teratomlar: 83 olgunun analizi. Türk Onkoloji Dergisi. 2010; 4: 97-102

14. Üstünyurt $E$, Güngör $T$, İskender $C$, Üstünyurt BO, Ümit B, Mollamahmutoğlu L. Tumor markers in mature cystic teratomas of the ovary. Arch Gynecol Obstet. 2009; 279: 145$47(13$

15. Frimer M, Seagle BI, Chudnoff S, Goldberg GL, Shabi S. Role of elevated cancer antigen 19-9 in women with mature cystic teratoma. Reprod Sci. 2014. 21: 1307-11

16. Kawai M, Kano T, Kikkawa $F$ et al. Seven tumor markers in benign and malign germ cell tumors of the ovary. Gynecol Oncol.1992; 45: 248-53.

17. Dede $M$, Güngör $S$, Yenen $C$, Alanbay İ, Duru NK, Haşimi A. Ca19-9 may have clinical significance in mature cystic teratomas of the ovary. Int J Gynecol Cancer. 2006; 16(1): 18993

18. Güzin $K$, Karaalp E, Gürgen $O$, Süer $N$, Öğütçüoğlu B, Örgül G. Ovaryan matür kistik teratom (dermoid kist) olgularında preoperatif tümör belirteçleri ve bu belirteçlerin ovaryan matür kistik teratomun boyutu ile korelasyonu. Türkiye Klinikleri Gynecol Obstet. 2012; 22(4): 216-9

19. Atabekoğlu C, Bozacı EA, Tezcan S. Elevated carbohydrate antigen 19-9 in a dermoid cyst. Int J Gynecol Obstet. 2005;91: 262-3

20. Ayhan A, Aksu T, Develioğlu O, Tuncer ZS, Ayhan A. Complications and bilaterality of mature ovarian teratomas (clinicopathological evaluation of 286 cases). Aust Nz J Obstet Gynaecol. 1991;31(1): 83-5 